\title{
Anestesia em Paciente Portador de Distrofia Muscular de Duchenne. Relato de Casos *
}

\section{Anesthesia for Duchenne Muscular Dystrophy Patients. Case Reports}

Rodrigo Machado Saldanha, TSA ${ }^{1}$; Juliano Rodrigues Gasparini, TSA ${ }^{2}$; Letícia Sales Silva ${ }^{3}$; Roberto Rigueti de Carli ${ }^{4}$; Victor Ugo Dorigo de Castilhos ${ }^{5}$; Mariana Moraes Pereira das Neves ${ }^{6}$; Fernando Paiva Araújo ${ }^{6}$; Paulo César de Abreu Sales, TSA ${ }^{7}$; José Francisco Nunes Pereira das Neves, TSA ${ }^{8}$

\begin{abstract}
RESUMO
Saldanha RM, Gasparini JR, Silva LS, Carli RR, Castilhos VUD, Neves MMP, Araújo FP, Sales PCA, Neves JFNP - Anestesia em Paciente Portador de Distrofia Muscular de Duchenne. Relato de Casos
\end{abstract}

JUSTIFICATIVA E OBJETIVOS: Este estudo objetiva relatar dois casos de anestesia em pacientes portadores de Distrofia Muscular de Duchenne (DMD), uma doença rara, progressiva e incapacitante, e discutir sobre a conduta anestésica. O comprometimento das funções pulmonar e cardíaca, a possibilidade de ocorrência de hipertermia maligna, a maior sensibilidade aos bloqueadores neuromusculares e o aumento da morbidade pós-operatória são alguns dos desafios enfrentados pelo anestesiologista.

RELATO DOS CASOS: O primeiro caso foi o de um paciente pediátrico com diagnóstico de DMD e rabdomiossarcoma, agendado para exérese da lesão e esvaziamento cervical ampliado. Na avaliação pré-anestésica (anamnese, exame clínico e exames complementares) não foram detectadas alterações, exceto pela tumoração cervical. Optou-se pela técnica venosa total, com remifentanil em infusão contínua e propofol em infusão alvo-controlada, sem a utilização de bloqueadores neuromusculares. O procedimento cirúrgico teve duração de 180 minutos, sem intercorrências. O segundo caso foi de um paciente do sexo masculino, 24 anos, com diagnóstico de DMD e colelitíase com indicação cirúrgica, cuja avaliação

* Recebido do (Received from) Hospital Monte Sinai, hospital agregado do CET/SBA do Hospital Universitário da Universidade Federal de Juiz de Fora (HU-UFJF), e no CET/SBA do Hospital Universitário São José, da Faculdade de Ciências Médicas de Minas Gerais

1. Instrutor do CET/SBA do HU-UFJF, Anestesiologista do Hospital Monte Sinai

2. Instrutor do CET/SBA do Hospital Universitário São José, da Faculdade de Ciências Médicas de Minas Gerais, Anestesiologista da Rede Sarah Kubitschek do Aparelho Locomotor

3. $M E_{1}$ do CET/SBA do Hospital Universitário São José, da Faculdade de Ciências Médicas de Minas Gerais

4. $M E_{2}$ do CET/SBA do Hospital Universitário da UFJF

5. $M E_{3}$ do CET/SBA do Hospital Universitário da UFJF

6. Acadêmico de Medicina, Estagiário do Serviço de Anestesiologia do Hospital Monte Sinai

7. Responsável pelo CET/SBA do Hospital Universitário São José da Faculdade de Ciências Médicas de Minas Gerais

8. Co-Responsável pelo CET/SBA do HU-UFJF; Anestesiologista do Hospital Monte Sinai

Apresentado (Submitted) em 28 de fevereiro de 2005

Aceito (Accepted) para publicação em 14 de abril de 2005

Endereço para correspondência (Correspondence to)

Dr. Rodrigo Machado Saldanha

Av. Vasconcellos, 56/401 Alto dos Passos

36026-480 Juiz de Fora, MG

E-mail:drigomg@terra.com.br

(c) Sociedade Brasileira de Anestesiologia, 2005 pré-operatória revelou pneumopatia restritiva grave, com diminuições da capacidade e da reserva respiratórias, sendo necessário o uso de BIPAP nasal noturno. Neste paciente, optou-se pela intubação traqueal com sedação mínima e anestesia tópica, seguida pela técnica venosa total com remifentanil em infusão contínua e propofol em infusão alvo-controlada, sem a utilização de bloqueadores neuromusculares. Ao término, o paciente foi extubado ainda na sala de operações e imediatamente colocado no BIPAP nasal. Encaminhado à UTI, com alta no $2^{\circ} \mathrm{PO}$ e alta hospitalar no $3^{\circ} \mathrm{PO}$. CONCLUSÕES: A anestesia venosa total com infusão contínua de propofol e remifentanil sem bloqueadores neuromusculares constitui-se em opção segura e eficiente nos portadores de DMD.

Unitermos: ANESTESIA, Venosa: total; DOENÇAS: distrofia muscular de Duchenne

\section{SUMMARY}

Saldanha RM, Gasparini JR, Silva LS, Carli RR, Castilhos VUD, Neves MMP, Araújo FP, Sales PCA, Neves JFNP - Anesthesia for Duchenne Muscular Dystrophy Patients. Case Reports

BACKGROUND AND OBJECTIVES: Reporting two cases of anesthesia in Duchenne Muscular Dystrophy (DMD) patients, which is an uncommon, progressive and disabling disease, and discussing anesthetic approaches, impairment of pulmonary and cardiac functions, the possibility of malignant hyperthermia, increased sensitivity to neuromuscular blockers and increased postoperative morbidity are some challenges faced by anesthesiologists.

CASE REPORTS: First case was a pediatric patient with DMD and rhabdomyosarcoma, scheduled for tumor excision and cervical emptying. During preanesthetic evaluation, history, clinical and additional exams, no changes were detected except for the cervical tumor. We decided for total intravenous anesthesia with remifentanil administered by continuous infusion and propofol by target-controlled infusion without neuromuscular blockers. Surgery lasted 180 minutes without intercurrences. The second case was a male patient, 24 years old, with DMD and cholelithiasis with surgical indication who, during preoperative evaluation, has revealed severe restrictive pneumopathy with decreased capacity and respiratory reserves and the need for nasal BIPAP at night. For this patient we decided for tracheal intubation with minimum sedation and topic anesthesia, followed by total intravenous anesthesia with remifentanil administered by continuous infusion and propofol by target-controlled infusion without neuromuscular blockers. At the end, patient was extubated still in to operating room and nasal BIPAP was immediately placed, being patient referred to the ICU. Patient was discharged from ICU in the $2^{\text {nd }} P O$ day and from hospital in the $3^{\text {rd }} \mathrm{PO}$ day.

CONCLUSIONS: Total intravenous anesthesia with propofol and remifentanil administered by continuous infusion without neuromuscular blockers is a safe and effective option for DMD patients.

Key Words: ANESTHESIA, Venous: total; DISEASES: Duchenne muscular dystrophy 


\section{INTRODUÇÃO}

A distrofia muscular de Duchenne (DMD) é uma doença rara, progressiva e incapacitante ${ }^{1}$, podendo culminar no óbito por disfunção ventilatória. Trata-se de afecção recessiva ligada ao cromossomo $\mathrm{X}$, sendo geralmente diagnosticada na infância ${ }^{2}$.

Os portadores de DMD, quando programados para um procedimento anestésico-cirúrgico, necessitam de cuidados especiais, como avaliação pré-anestésica detalhada, com anamnese e exame físico dirigidos, cuidadosa seleção da técnica e dos agentes anestésicos e atenta monitorização pós-operatória, pelo risco de complicações nesse período ${ }^{2}$. O comprometimento das funções pulmonar e cardíaca, a possibilidade de ocorrência de hipertermia maligna, a maior sensibilidade aos bloqueadores neuromusculares e aumento da morbidade pós-operatória são alguns dos desafios enfrentados pelo anestesiologista.

O presente trabalho tem como finalidade relatar dois casos de anestesia venosa total em pacientes portadores de DMD.

\section{RELATO DOS CASOS}

Caso 1: Paciente do sexo masculino, 5 anos, $20 \mathrm{~kg}$, estado físico ASA II, com diagnósticos de DMD e rabdomiossarcoma, agendado para exérese da lesão e esvaziamento cervical ampliado. Na avaliação pré-anestésica, notava-se tumoração cervical, FC, PA e ausculta pulmonar normais, com exames complementares (incluindo ECG e ecocardiograma) sem alterações. A medicação pré-anestésica foi feita com midazolam (5 mg) por via oral. Na sala de operações foi monitorizado com estetoscópio precordial, $\mathrm{SpO}_{2}$, eletrocardiografia e PANI, seguindo-se a venóclise com cateter $20 \mathrm{G}$. Após oxigenação com $\mathrm{O}_{2}$ a $100 \%$ por 3 minutos, procedeu-se à indução anestésica com remifentanil em infusão contínua $\left(0,5 \mu \mathrm{g} \cdot \mathrm{kg}^{-1} \cdot \mathrm{min}^{-1}\right)$ e propofol em infusão alvo-controlada (6 $\left.\mu \mathrm{g} \cdot \mathrm{mL}^{-1}\right)$, sem utilização de bloqueadores neuromusculares, com posterior intubação orotraqueal com tubo de $6 \mathrm{~mm}$ sem balonete. O paciente foi mantido com ventilação mecânica em sistema fechado com reabsorção de $\mathrm{CO}_{2}$ e monitorização da $\mathrm{P}_{\mathrm{ET}} \mathrm{CO}_{2}$. Ainfusão de remifentanil $\left(0,3 \mu \mathrm{g} \cdot \mathrm{kg}^{-1} \cdot \mathrm{min}^{-1}\right) \mathrm{e}$ propofol $\left(3 \mu \mathrm{g} \cdot \mathrm{mL}^{-1}\right)$ objetivou manter parâmetros de FC entre 80 e 90 bpm e de PAS/PAD entre $90-80 / 50-40$ mmHg, respectivamente. O procedimento cirúrgico teve duração de 180 minutos, sem intercorrências. Ao término o paciente apresentou um despertar tranqüilo aproximadamente $7 \mathrm{mi}-$ nutos após a interrupção da infusão dos agentes anestésicos. A analgesia pós-operatória foi feita com nalbufina $(0,2$ $\left.\mathrm{mg} \cdot \mathrm{kg}^{-1}\right)$ e dipirona $\left(50 \mathrm{mg} \cdot \mathrm{kg}^{-1}\right)$. Encaminhado à sala de recuperação pós-anestésica, onde permaneceu por 120 minutos, sem intercorrências. A alta hospitalar foi no $3^{\circ}$ dia de pós-operatório.

Caso 2: Paciente do sexo masculino, 24 anos, com os diagnósticos de DMD e colelitíase e indicação cirúrgica. A avaliação pré-operatória revelou pneumopatia restritiva grave, com diminuições da capacidade e da reserva respiratórias, sendo necessário o uso de BIPAP nasal noturno. Não havia cardiopatia, sendo classificado como estado físico ASA III. Após discussão do caso com a equipe cirúrgica e consentimento informado do paciente e de seus familiares a respeito do risco anestésico, agendou-se colecistectomia videolaparoscópica eletiva. Após monitorização habitual com cardioscopia contínua, pressão arterial não-invasiva e oximetria de pulso, foi realizada sedação com propofol (15 mg), por via venosa e lidocaína tópica oral $(20 \mathrm{~mL})$, para intubação traqueal com fibroscópio flexível. Realizada a intubação e confirmada pela capnografia, foi induzida anestesia geral venosa total com infusão alvo-controlada de propofol a 1\% (alvo de 2,9 $\left.\mu \mathrm{g} \cdot \mathrm{ml}^{-1}\right)$ e infusão contínua de remifentanil $(0,3$ $\left.\mu \mathrm{g} \cdot \mathrm{kg}^{-1} \cdot \mathrm{min}^{-1}\right)$, sem utilização de bloqueadores neuromusculares. O paciente foi ventilado com mistura de $\mathrm{O}_{2}(40 \%)$ e ar comprimido medicinal $(60 \%)$, com aparelho ciclado à pressão. Recebeu no intra-operatório $1500 \mathrm{~mL}$ de solução fisiológica a $0,9 \%$, mantendo-se hemodinamicamente estável durante todo procedimento, que durou aproximadamente 40 minutos. Ao término, ele foi extubado ainda na SO e imediatamente colocado no BIPAP nasal com pressão de suporte de $15 \mathrm{cmH}_{2} \mathrm{O}$, PEEP de $8 \mathrm{cmH}_{2} \mathrm{O}$ e $\mathrm{FIO}_{2}$ de 0,21 . Foi encaminhado à UTI em alerta, atendendo a comandos verbais e queixando-se apenas de dor na região da incisão. O exame físico era normal. Teve alta da UTI no $2^{\circ} \mathrm{PO}$, sem intercorrências e alta hospitalar no $3^{\circ} \mathrm{PO}$.

\section{DISCUSSÃO}

O termo distrofia muscular se refere a um grupo de doenças genéticas degenerativas que afetam progressivamente a musculatura esquelética, sem qualquer anormalidade do neurônio motor ${ }^{3,4}$. A distrofia muscular de Duchenne, também chamada de Distrofia Muscular Pseudohipertrófica, é o tipo mais comum dentre as distrofias musculares ${ }^{3,4}$. Causada por mutações no braço curto do cromossomo X, a DMD afeta principalmente meninos, que herdam a doença das mães ${ }^{1}$ (herança autossômica recessiva); as mulheres normalmente não exibem sintomatologia ${ }^{3}$. Os portadores de DMD têm deleções moleculares nos genes da distrofina, levando à quebra da translação desta proteína e subseqüente defeito na membrana celular das células musculares ${ }^{1}$. Aincidência é de 3 para cada 10.000 nascidos vivos ${ }^{1}$.

Esta desordem é tipicamente diagnosticada após os dois anos de idade, quando passam a ser evidentes os sinais e sintomas como fraqueza muscular, que se inicia nos quadris, região pélvica, coxas e ombros, com pseudohipertrofia de vários grupos musculares, por exemplo, os da panturriIha ${ }^{1}$. A confirmação diagnóstica se dá através de biópsia muscular $^{2}$.

A doença é progressiva, podendo, eventualmente, afetar todos os músculos esqueléticos, inclusive a musculatura respiratória e o coração. Os portadores de DMD dificilmente vivem após os 30 anos de idade ${ }^{1}$. Graves infecções pulmonares são a principal causa de óbitos ${ }^{2}$.

As preocupações anestésico-cirúrgicas recaem principalmente sobre as funções pulmonar e cardíaca, que devem ser 
avaliadas criteriosamente devido ao prejuízo da função muscular. Estudos mostraram que $83 \%$ destes pacientes têm alterações do ECG, 26\% apresentam insuficiência cardíaca, $31 \%$ exibem alterações na radiografia de tórax e $73 \%$ têm restrição pulmonar grave ${ }^{2}$. Com freqüência, estes pacientes desenvolvem cardiomiopatia dilatada que pode estar associada com incompetência da valva mitral $\left(25 \%\right.$ dos casos) ${ }^{5}$. Disritmias cardíacas e defeitos da condução elétrica também são comuns ${ }^{4}$ Cifoescoliose é outra condição freqüente, causando restrição pulmonar e muitas vezes necessitando tratamento cirúrgico. A diminuição dos reflexos laríngeos e o prolongamento do tempo de esvaziamento gástrico aumentam o risco de aspiração ${ }^{3}$; assim, estes pacientes devem ser considerados de "estômago cheio" 5 . Febre, sintomas de rabdomiólise (hipercalemia, mioglobinúria) e espasmo de masseter são complicações descritas nas anestesias destes pacientes $^{2}$.

No preparo pré-operatório, deve-se limitar a sedação ${ }^{3}$. A succinilcolina e todos os anestésicos halogenados devem ser evitados pela possibilidade de desencadearem hipertermia maligna ${ }^{2,3,6}$. Além disso, os agentes inalatórios, principalmente o halotano, além de deprimirem a respiração, estão também relacionados à elevação maciça da CPK, mioglobinúria e parada cardiocirculatória (PCR) nestes pacientes $^{2,3}$. A succinilcolina foi proscrita pelo Food and Drug Administration, nos portadores de DMD, após observação de diversos casos de rabdomiólise e PCR por hipercalemia. ${ }^{3}$. A anestesia regional pode ser uma boa alternativa, quando possível, por causar depressão mínima dos sistemas respiratório e cardiovascular e exigir pouca manipulação de vias aéreas ${ }^{2}$.

A anestesia venosa total pode ser utilizada, desde que se tome cuidado com a cardiodepressão causada por alguns agentes e com a sensibilidade individual à depressão respiratória $^{2,3}$. Pacientes com DMD têm sensibilidade aumentada aos bloqueadores neuromusculares não-despolarizantes, embora possam ser utilizados de maneira segura com monitorização adequada ${ }^{4}$; optou-se, no caso 1 , pela IOT sem a utilização destes fármacos. Estudos mostram que é possível obterem-se excelentes condições para IOT em pacientes pediátricos com a associação do propofol com um agente opióide, em especial o remifentanil, desde que em doses adequadas $^{7,10}$. No caso 2, a opção foi pela IOT com sedação mínima e anestesia tópica, pela gravidade da pneumopatia do paciente, associada ao risco de broncoaspiração.

Pelo risco aumentado de hipertermia maligna, o ideal é que sejam utilizados circuitos respiratórios novos, ou que estes sejam lavados com fluxo de oxigênio a $100 \%$ por 20 a 30 minutos ${ }^{11}$.

Especial atenção deve ser dada ao pós-operatório, quando é freqüente a necessidade de assistência ventilatória ${ }^{2}$.

Os casos demonstraram que a anestesia venosa total com propofol e remifentanil, sem utilização de bloqueadores neuromusculares, constituiu-se em opção segura e eficiente em pacientes portadores da DMD.

Revista Brasileira de Anestesiologia

Vol. 55, No 4, Julho - Agosto, 2005

\section{Anesthesia for Duchenne Muscular Dystrophy Patients. Case Reports}

Rodrigo Machado Saldanha, TSA, M.D.; Juliano Rodrigues Gasparini, TSA, M.D.; Letícia Sales Silva, M.D.; Roberto Rigueti de Carli, M.D.; Victor Ugo Dorigo de Castilhos, M.D.; Mariana Moraes Pereira das Neves, Fernando Paiva Araújo, Paulo César de Abreu Sales, TSA, M.D.; José Francisco Nunes Pereira das Neves, TSA, M.D.

\section{INTRODUCTION}

Duchenne muscular dystrophy (DMD) is an uncommon, progressive and disabling disease ${ }^{1}$, which may evolve to death by ventilatory dysfunction. It is a recessive disease bound to chromosomeX and in general diagnosed during childhood ${ }^{2}$. DMD patients scheduled to surgical procedures demand special care, such as detailed preanesthetic evaluation with history and specific physical evaluation, careful choice of anesthetic technique and agents and vigilant postoperative monitoring for the risk of complications during this period ${ }^{2}$. Pulmonary and cardiac function impairment, the chance of malignant hyperthermia occurrence, increased sensitivity to neuromuscular blockers and increased postoperative morbidity are some challenges faced by anesthesiologists.

This study aimed at reporting two cases of total intravenous anesthesia in DMD patients.

\section{CASE REPORTS}

Case 1: Male patient, 5 years old, $20 \mathrm{~kg}$, physical status ASA II, with DMD and rhabdomyosarcoma, scheduled for tumor excision and cervical emptying. At preanesthetic evaluation cervical tumor was observed, HR BP and pulmonary auscultation were normal with normal additional exams, including electrocardiogram (ECG) and echocardiogram (EEG). Patient was premedicated with oral midazolam (5 $\mathrm{mg}$ ). Monitoring in the operating room consisted of precordial stethoscope, $\mathrm{SpO}_{2}, \mathrm{ECG}$ and PANI, followed by venoclysis with $20 \mathrm{G}$ catheter. After oxygenation with $100 \%$ oxygen during 3 minutes, anesthesia was induced with remifentanil continuous infusion $\left(0.5 \mu \mathrm{g} \cdot \mathrm{kg}^{-1} \cdot \mathrm{min}^{-1}\right)$ and propofol in target-controlled infusion $\left(6 \mu \mathrm{g} \cdot \mathrm{mL}^{-1}\right)$ without neuromuscular blockers, followed by tracheal intubation with $6 \mathrm{~mm}$ tube without cuff. Patient was kept under mechanical ventilation in closed system with $\mathrm{CO}_{2}$ reabsorption and $\mathrm{P}_{\mathrm{ET}} \mathrm{CO}_{2}$ monitoring. Remifentanil $\left(0.3 \mu \mathrm{g} \cdot \mathrm{kg}^{-1} \cdot \mathrm{min}^{-1}\right)$ and propofol $\left(3 \mu \mathrm{g} \cdot \mathrm{mL}^{-1}\right)$ infusion aimed at maintaining $\mathrm{HR}$ between 80 and $90 \mathrm{bpm}$ and SBP/DBP between 90-80/50-40 mmHg, respectively. Surgery lasted 180 minutes without intercurrences. Patient had a quiet emergence approximately 7 minutes after anesthetic agents withdrawal. Postoperative analgesia was achieved with nalbuphine $\left(0.2 \mathrm{mg} \cdot \mathrm{kg}^{-1}\right)$ and dipirone $\left(50 \mathrm{mg} \cdot \mathrm{kg}^{-1}\right)$. Patient was referred to the PACU where he remained for 120 minutes without intercurrences. Patient was discharged in the $3^{\text {rd }}$ postoperative day. 
Case 2: Male patient, 24 years old, with DMD and cholelithiasis and surgical indication. Preoperative evaluation has revealed severe restrictive pneumopathy with decreased capacity and respiratory reserves, with the need for nasal BIPAP at night. There was no cardiac disease and patient was classified as physical status ASA III. After discussing the case with the surgical team and the informed consent of patient and relatives about anesthetic risks, elective videolaparoscopic cholecystectomy was scheduled. After routine monitoring with continuous cardioscopy, noninvasive blood pressure and pulse oximetry, patient was sedated with intravenous propofol ( $15 \mathrm{mg})$ and oral topic lidocaine $(20 \mathrm{~mL})$ for tracheal intubation with flexible fiberscope. After intubation performed and confirmed by capnography, total intravenous general anesthesia was induced with propofol in target-controlled infusion (target of $2.9 \mu \mathrm{g} \cdot \mathrm{mL}^{-1}$ ) and remifentanil continuous infusion $\left(0.3 \mu \mathrm{g} \cdot \mathrm{kg}^{-1} \cdot \mathrm{min}^{-1}\right)$ without neuromuscular blockers. Patient was ventilated with $\mathrm{O}_{2}$ $(40 \%)$ and medicinal compressed air $(60 \%)$ with pressure-cycled device. In the intraoperative period patient received $1500 \mathrm{~mL}$ of $0.9 \%$ saline solution and was maintained hemodynamically stable throughout the procedure which lasted approximately 40 minutes.

At the end, patient was extubated still in the OR and nasal BIPAP was immediately installed with support pressure of 15 $\mathrm{cmH}_{2} \mathrm{O}$, PEEP of $8 \mathrm{cmH}_{2} \mathrm{O}$ and $\mathrm{FIO}_{2}$ of 0.21 . Patient was referred awaken to the ICU, responding to verbal commands and just complaining of pain at incision site. Physical evaluation was normal. Patient was discharged from ICU in the $2^{\text {nd }}$ $\mathrm{PO}$ day and from hospital in the $3^{\text {rd }} \mathrm{PO}$ day.

\section{DISCUSSION}

Muscular dystrophy is a term used to define a group of degenerative genetic diseases progressively affecting skeletal muscles, with no motor neuron abnormality ${ }^{3,4}$. Duchenne muscular dystrophy, also called Pseudohypertrophic Muscular Dystrophy, is the most common among muscular dystrophies ${ }^{3,4}$. Caused by mutations in the short arm of chromosome X, DMD affects mainly boys, who inherit the disease from their mothers ${ }^{1}$ (recessive autonomic heritage); women are in general asymptomatic ${ }^{3}$. DMD patients have molecular deletions on dystrophine genes, leading to the breakdown of this protein translation and subsequent defect on muscle cells membrane ${ }^{1}$. Incidence is 3 to every 10,000 live borns ${ }^{1}$. This disorder is typically diagnosed after 2 years of age, when signs and symptoms, such as muscle weakness, start to become evident. Symptoms start in hips, pelvic region, thighs and shoulders, with pseudodystrophy of several muscle groups, such as calf's muscles ${ }^{1}$. Diagnostic is confirmed by muscle biopsy ${ }^{2}$.

It is a progressive disease which may end up affecting all skeletal muscles, including respiratory and cardiac muscles.
DMD patients seldom live beyond 30 years of age ${ }^{1}$. Severe pulmonary infections are the major cause of mortality ${ }^{2}$. Anesthetic-surgical concerns are mainly pulmonary and cardiac functions, which should be carefully monitored due to muscle function impairment. Studies have shown that $83 \%$ of these patients have ECG abnormalities, $26 \%$ present heart failure, $31 \%$ have chest $X$-rays changes, and $73 \%$ have severe pulmonary restriction ${ }^{2}$. Very often, these patients develop dilated cardiopathy which may be associated to mitral valve incompetence $\left(25 \%\right.$ of cases) ${ }^{5}$.

Cardiac arrhythmias and electric conduction defects are also common ${ }^{4}$. Kyphoscoliosis is another frequent condition, causing pulmonary restriction and very often requiring surgical treatment. Decreased laryngeal reflexes and prolonged gastric emptying time increase the risk of aspiration ${ }^{3}$ and these patients should always be considered "full stomach" patients ${ }^{5}$. Fever, symptoms of rhabdomyolisis (hyperkalemia, mioglobinuria) and masseter spasm are complications described during anesthetic induction of these patients ${ }^{2}$.

Sedation should be limited during preoperative medication ${ }^{3}$. Succinylcholine and all halogenate anesthetic agents should be avoided for the possibility of triggering malignant hyperthermia ${ }^{2,3,6}$. Inhalational anesthetics, especially halothane, in addition to depressing breathing are also related to massive increase in CPK and myoglobinuria, and to cardiocirculatory arrest (CCA) in these patients ${ }^{2,3}$.

The Food and Drug Administration banned succinylcholine for DMD patients after the observation of several rhabdomyolisis cases and PCR by hyperkalemia ${ }^{3}$. Regional anesthesia could be a good alternative, when possible, for minimally depressing respiratory and cardiovascular systems and requiring minor airway manipulation ${ }^{2}$.

Total intravenous anesthesia may be used, provided care is taken with cardiac depression caused by some agents, and with individual sensitivity to respiratory depression ${ }^{2,3}$. DMD patients have increased sensitivity for nondepolarizing neuromuscular blockers and, although they may be safely used with adequate monitoring ${ }^{4}$, in case 1 we decided for $\mathrm{TI}$ without these drugs. Studies have shown that it is possible to achieve excellent TI conditions in pediatric patients with the association of propofol to an opioid, especially remifentanil, provided adequate doses are used ${ }^{7,10}$. For case 2, our option was TI with minimum sedation and topic anesthesia, for the severity of patient's pneumopathy, associated to the risk of bronchoaspiration.

Because there is increased risk of malignant hyperthermia, the ideal is to use new breathing circuit, or at least that they are washed with $100 \%$ oxygen for 20 to 30 minutes ${ }^{11}$.

Special attention should be given to the postoperative period where ventilatory assistance is often required ${ }^{2}$.

Our cases have shown that total intravenous anesthesia with propofol and remifentanil, without neuromuscular blockers, was a safe and effective option for DMD patients. 


\section{REFERÊNCIAS - REFERENCES}

01. Rossbach HC, Lacson A, Grana NH et al - Duchenne muscular dystrophy and concomitant metastatic alveolar rhabdomyosarcoma. J Pediatr Hematol Oncol, 1999;21: 528-530.

02. Tonelli D, Pinho I, Sacco PCN et al - Anestesia em paciente com distrofia muscular de Duchenne. Relato de caso. Rev Bras Anestesiol, 2003;53:392-393.

03. Stevens RD - Neuromuscular disorders and anesthesia. Curr Opin Anaesth, 2001;14:693-698.

04 Gregory J, McGoldrick KE - Anesthetic implications of neuromuscular disease. Surv Anesthesiology, 2004;48:213.

05. Le Corre F, Plaud B - Neuromuscular disorders. Curr Opin Anesthesiol, 1998;11:333-337

06. Martz DG, Matjasko MJ - Neurological Diseases, em: Benumof $\mathrm{JL}$ - Anesthesia and Uncommon Diseases. Philadelphia, PA: Saunders; 1998;3-29

07. Morgan JM, Eissa A, Barker I et al - Comparison of intubating conditions in children after induction of anesthesia following propofol and suxamethonium with propofol and remifentanil. Paediatr Anaesth, 2004;14:707.

08 Blair JM, Hill DA, Wilson CM et al - Assessment of tracheal intubation in children after induction with propofol and different doses of remifentanil. Anaesthesia, 2004;59:27-33.

09 Leone M, Rousseau S, Avidan M et al - Target concentrations of remifentanil with propofol to blunt coughing during intubation, cuff inflation and tracheal suctioning. $\mathrm{Br} \mathrm{J}$ Anaesth, 2004; $93: 660-663$

10. Capozzoli G, Auricchio F, Accinelli G - Total intravenous anaesthesia without muscle relaxants in a child with diagnosed Duchenne muscular. Minerva Anesthesiol, 2000;66:839-840.

11. Halsall PJ, Ellis FR - Malignant hyperthermia. Anaesth Intensive Care Med, 2002;3:222-225.

\section{RESUMEN}

Saldanha RM, Gasparini JR, Silva LS, Carli RR, Castilhos VUD, Neves MMP, Araújo FP, Sales PCA, Neves JFNP - Anestesia en un Paciente Portador de Distrofia Muscular de Duchenne. Relato de Casos

JUSTIFICATIVA Y OBJETIVOS: Relatar dos casos de anestesia en pacientes portadores de Distrofia Muscular de Duchenne (DMD), una enfermedad rara, progresiva e incapacitante, y discutir sobre la conducta anestésica y comprometimiento de las funciones pulmonar y cardiaca, la posibilidad de ocurrencia de hipertermia maligna, la mayor sensibilidad a los bloqueadores neuromusculares y el aumento de la morbidad pos-operatoria son algunos de los desafíos enfrentados por el Anestesiologista.

RELATO DE LOS CASOS: El primer caso fue el de un paciente pediátrico con diagnóstico de DMD y rabdomiosarcoma, agendado para exéresis de la lesión y vaciamiento cervical ampliado. En la evaluación pre-anestésica, anamnesis, examen clínico y exámenes complementarios no fueron detectadas alteraciones, excepto por la tumoración cervical. Se optó por la técnica venosa total, con remifentanil en infusión continuada y propofol en infusión mira-controlada, sin la utilización de bloqueadores neuromusculares. El procedimiento quirúrgico tuvo duración de 180 minutos, sin intercurrencias. El segundo caso fue de un paciente del sexo masculino, 24 años, con diagnóstico de DMD y colelitiasis con indicación quirúrgica, en el cual la evaluación pre-operatoria reveló pneumopatia restrictiva grave, con disminuciones de la capacidad y de la reserva respiratorias, siendo necesario el uso de BIPAP nasal nocturno. En este paciente, se optó por la intubación traqueal con sedación mínima y anestesia tópica, seguida por la técnica venosa total con remifentanil en infusión continuada y propofol en infusión mira-controlada, sin la utilización de bloqueadores neuromusculares. Al término, el paciente fue extubado aún en la sala del operaciones e inmediatamente colocado en el BIPAP nasal. Encaminado a la UTI, con alta en el $2^{\circ} \mathrm{PO}$ y alta hospitalaria en el $3^{\circ} \mathrm{PO}$.

CONCLUSIONES: La anestesia venosa total con infusión continuada de propofol y remifentanil sin bloqueadores neuromusculares, constituye una opción segura y eficiente en los portadores de DMD. 